\title{
A Rapid Bioassay for Screening Rhizosphere Microorganisms for Their Ability to Induce Systemic Resistance
}

\author{
D. Y. Han, D. L. Coplin, W. D. Bauer, and H. A. J. Hoitink
}

First and second authors: Department of Plant Pathology; and third author: Department of Horticulture and Crop Sciences, The Ohio State University, Columbus 43210; and fourth author: Department of Plant Pathology, The Ohio State University, Ohio Agricultural Research and Development Center, Wooster 44691.

Accepted for publication 10 January 2000.

\begin{abstract}
Han, D. Y., Coplin, D. L., Bauer, W. D., and Hoitink, H. A. J. 2000. A rapid bioassay for screening rhizosphere microorganisms for their ability to induce systemic resistance. Phytopathology 90:327-332.

We developed a rapid and miniaturized bioassay for screening large numbers of rhizosphere microorganisms for their ability to induce systemic resistance to bacterial leaf spot of radish caused by Xanthomonas campestris pv. armoraciae. In this bioassay, Pantoea agglomerans strain

ling roots to the foliage. This suggests that induction of systemic resistance could best explain the observed reduction in disease severity. Three mini- $\mathrm{Tn} 5 \mathrm{Km}$-induced mutants of strain E278Ar were isolated that had lost the ability to induce resistance. The bioassay also was used to demonstrate that the fungal biocontrol agent Trichoderma hamatum strain 382 induces systemic resistance in radish. The bioassay required only 14 to 18 days from seeding until rating for disease severity, which is 10 to 14 days less than earlier bioassays.
\end{abstract} E278Ar controlled symptoms of disease as effectively as 2,6-dichloroisonicotinic acid when applied to the roots of seedlings produced in growth pouches in a soilless system. E278Ar essentially did not migrate from seed-
Additional keywords: biological control.
Since 1991, several reports have shown that some rhizosphere microorganisms can induce systemic resistance in plants to root and foliar diseases. For example, the plant growth-promoting rhizobacteria Pseudomonas fluorescens strain 89B-27 and Serratia marcescens strain 90-166 can induce systemic resistance in cucumber to anthracnose (43), Fusarium wilt (20), angular leaf spot (21), and Cucumber mosaic virus (31) under greenhouse and field conditions (44) when applied as seed treatments. Plant growth-promoting fungi isolated from the rhizosphere of zoysiagrass plants can induce systemic resistance in cucumber against anthracnose (23). Trichoderma harzianum strain T39 can induce resistance to Botrytis cinerea in tomato, pepper, bean, lettuce, and tobacco (6). These microorganisms induce a systemic effect against pathogens while remaining spatially separated on the plant. This type of systemic resistance induced by nonpathogenic microorganisms has been named induced systemic resistance (ISR) $(14,29)$ to distinguish it from systemic acquired resistance (SAR) induced by necrotizing plant pathogens $(4,32-34)$.

SAR always is accompanied by an increase in the concentration of salicylic acid (SA) and induction of pathogenesis-related (PR) proteins in the plant $(11,12,24,27,33,36-38,41,42)$. Exogenously applied SA (27) and other chemicals such as the SA analogs 2,6dichloroisonicotinic acid (INA) (41) and benzothiadiazoles $(8,15)$ can also induce SAR. Various pesticides have also been implicated as SAR inducers (13). These chemicals induce the accumulation of PR proteins (1). In contrast, ISR induced by nonpathogenic rhizosphere microorganisms does not involve the SA signaling pathway or the induction of PR proteins $(10,28,29)$. Jasmonic acid and ethylene activate the ISR signaling pathway (29). Recent work by Mitter

Corresponding author: H. A. J. Hoitink; E-mail address: hoitink.1@ osu.edu

Publication no. P-2000-0224-02R

This article is in the public domain and not copyrightable. It may be freely reprinted with customary crediting of the source. The American Phytopathological Society, 2000. et al. (26) identified a gene encoding a defensin from Arabidopsis thaliana (PDF 1.2) that is inducible by jasmonic acid, but not by SA. It seems likely that both systems operate independently in plants. Indeed, Van Wees and colleagues $(39,40)$ showed that Arabidopsis plants in which both ISR, induced by a plant growth-promoting rhizobacterium, and SAR, induced by a pathogen or SA, exhibited additive effects on the level of resistance against Pseudomonas syringae pv. tomato. In summary, knowledge of how biocontrol agents induce systemic resistance may be important for effective application of this approach to biological control.

Little is known about how beneficial microorganisms induce systemic resistance in plants. The lipopolysaccharide O-antigen of Pseudomonas fluorescens strain WCS374 plays a role in ISR induced in radish against Fusarium wilt $(18,19)$. The degree of resistance induced in radish is affected by the levels of iron available in the growth medium (17). Press et al. (30) demonstrated that although $S$. marcescens strain 90-166 produces SA, mutants unable to produce SA still induce resistance. However, Maurhofer et al. (22) showed that introduction of genes for SA biosynthesis into a strain of Pseudomonas fluorescens that did not produce SA, but induced resistance in tobacco against Tobacco necrosis virus, dramatically increased its ability to induce systemic resistance. Finally, mycelial extracts of Trichoderma can induce systemic resistance and PR proteins in tobacco (2).

Research on mechanisms by which rhizosphere microorganisms induce ISR can require screening large numbers of mutants of various bacterial strains or fungal isolates. Although several bioassays have been developed to examine the ability of biocontrol agents to induce resistance $(18,19,31,43)$, a need still exists for a more miniaturized, reproducible, and rapid method for screening large numbers of potential inducers of resistance or for screening mutants of a known inducer to determine the mechanism by which resistance is induced. The cucumber seed treatment bioassay $(31,43)$ requires a large amount of greenhouse bench space and 3 to 4 weeks to complete. The rockwool radish and Arabidopsis bioassays developed by Leeman et al. $(18,19)$ require approximately 4 weeks for symp- 
tom development. A bioassay requiring less time and space, while maintaining spatial separation between the inducing biocontrol agent and the pathogen on the plant, is needed.

The objectives of this study were to (i) develop a rapid and miniaturized laboratory bioassay for screening rhizosphere microorganisms for their abilities to induce systemic resistance; (ii) determine whether the degree of resistance induced by these microorganisms is comparable to that induced by chemicals; and (iii) demonstrate the use of this bioassay in isolating mutants of a biocontrol agent that are unable to induce systemic resistance. We report the development of a growth pouch bioassay that requires only 14 to 18 days from the time of seeding until rating for disease severity. This assay was used to evaluate the efficacy of Pantoea agglomerans strain $\mathrm{E} 278 \mathrm{Ar}$ as an inducer of systemic resistance and to isolate mutants of E278Ar that had lost the ability to induce systemic resistance. In addition, this bioassay was used to demonstrate that the fungal biocontrol agent $T$. hamatum strain 382 induces systemic resistance.

\section{MATERIALS AND METHODS}

Biocontrol agents. $P$. agglomerans strain E278A was isolated from a composted hardwood bark potting mix (16). Strain E278Ar, a spontaneous mutant resistant to rifampicin, was isolated by streak-
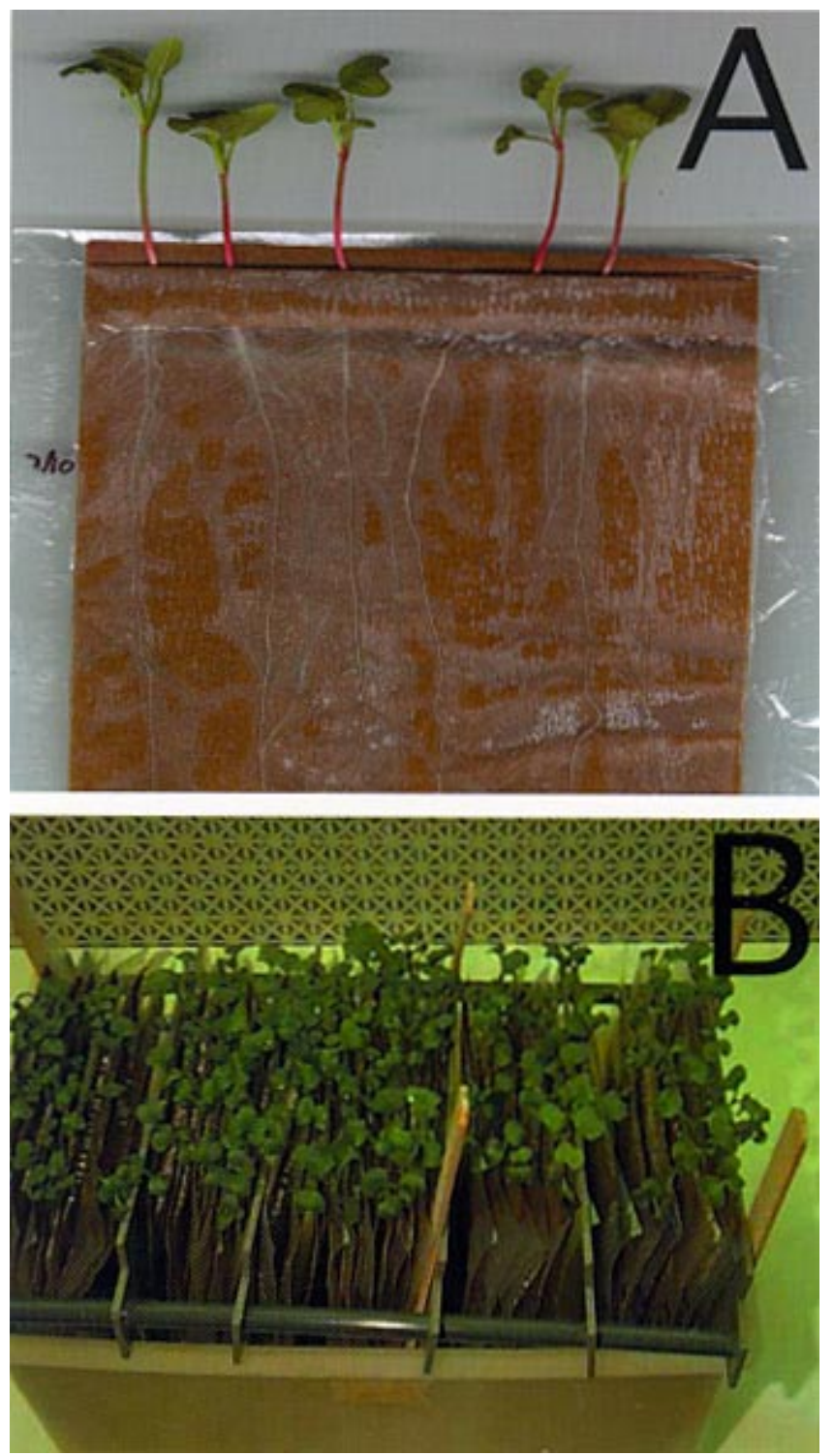

Fig. 1. A, Radish seedlings in growth pouches. B, Growth pouches arranged in holding racks. ing E278Ar onto 0.1× Trypticase soy agar (BBL; Becton Dickinson, Franklin Lakes, NJ) with $50 \mu \mathrm{g}$ of rifampicin per ml. Xanthomonas campestris pv. armoraciae strain 704b was isolated from radish in Ohio (35). Strain 704b is naturally resistant to $100 \mu \mathrm{g}$ of streptomycin per ml. T. hamatum strain 382 inoculum was received as a granular preparation from Sylvan Bioproducts, Inc., Cabot, PA. T. hamatum strain 382 also was isolated originally from a composted hardwood bark potting mix (16).

Growth of radish seedlings. Radish seeds (Raphanus sativus L. cv. Fuego) were surface-sterilized for 10 to $15 \mathrm{~min}$ in $0.05 \%$ sodium hypochlorite and rinsed five times with autoclaved tap water. Seeds were then planted in growth pouches (Mega International, St. Paul, MN) consisting of an autoclavable plastic pouch into which a paper wick was placed. The paper was folded at the top of the pouch to provide a trough for planting seeds. The fold of the trough was perforated to allow downward penetration of roots (Fig. 1A). The pouches were wetted with $10 \mathrm{ml}$ of $0.25 \times$ modified Hoagland's solution (9) containing $5 \mathrm{mM} \mathrm{Ca}\left(\mathrm{NO}_{3}\right)_{2} \cdot 4 \mathrm{H}_{2} \mathrm{O}, 5 \mathrm{mM} \mathrm{KNO} \mathrm{KN}_{3}, 2 \mathrm{mM}$ $\mathrm{MgSO}_{4} \cdot 7 \mathrm{H}_{2} \mathrm{O}, 0.1 \mathrm{mM} \mathrm{KH} \mathrm{PO}_{4}, 0.1 \mathrm{mM} \mathrm{K} \mathrm{HPO}_{4}, 0.2 \mathrm{mM} \mathrm{MgCl}$. $6 \mathrm{H}_{2} \mathrm{O}$, and $0.0235 \mathrm{~g}$ of Sequestrene 138 (Novartis Crop Protection, Basel, Switzerland) per liter, $\mathrm{pH}$ 6.6, and autoclaved. Pouches were then planted with the surface-sterilized radish seeds (six seeds per pouch), placed in holding racks (Fig. 1B), covered with aluminum foil, and incubated in a growth chamber (Percival Manufacturing, Boone, IA) at $25^{\circ} \mathrm{C}$. The aluminum foil was removed after incubation in darkness for $20 \mathrm{~h}$. Seedlings were then incubated under continuous illumination ( 30 to $47 \mu \mathrm{E} \mathrm{m} \mathrm{min}^{-1}$ ) and thinned to five plants per pouch 3 days after germination. Pouches were watered regularly with autoclaved tap water, using a pipet, to keep the paper wick moist; standing water in the bottom of the pouches was avoided. Pouches were fertilized once per week with $0.25 \times$ autoclaved modified Hoagland's solution.

Root treatment with the biocontrol agents and INA. $P$. agglomerans strain E278Ar was grown for $20 \mathrm{~h}$ at $30^{\circ} \mathrm{C}$ in L-broth (25) with rifampicin $(50 \mu \mathrm{g} / \mathrm{ml})$ on a rotary shaker at $200 \mathrm{rpm}$. Thereafter, cultures were centrifuged at $3,840 \times g$ for $10 \mathrm{~min}$ and the supernatant was discarded. Cells of E278Ar were resuspended in autoclaved $0.25 \times$ modified Hoagland's solution, and $200 \mu \mathrm{l}$ of a $1 \times 10^{9}-\mathrm{CFU} / \mathrm{ml}$ suspension was then pipetted directly onto the

TABLE 1. Suppression of bacterial leaf spot of radish and the population of Xanthomonas campestris pv. armoraciae strain 704b in leaves after root treatment with the biocontrol agent Pantoea agglomerans strain E278Ar

\begin{tabular}{lccc}
\hline $\begin{array}{l}\text { Root } \\
\text { treatment }\end{array}$ & $\begin{array}{c}\text { Pathogen } \\
\text { inoculation }\end{array}$ & $\begin{array}{c}\text { Mean disease } \\
\text { severity }\end{array}$ & $\begin{array}{c}\text { Populations of 704b } \\
\text { (log CFU/g fresh wt) }\end{array}$ \\
\hline Control & - & 1.0 & $<1.5$ \\
Control & + & 3.2 & 8.5 \\
E278Ar & + & 2.2 & 7.4 \\
INA & + & 2.3 & 6.9 \\
LSD $_{0.05}{ }^{\mathrm{d}}$ & & 0.5 & 0.9 \\
\hline
\end{tabular}

a Roots were treated 3 days after germination with $200 \mu$ l of autoclaved $0.25 \times$ modified Hoagland's solution (control), $200 \mu \mathrm{l}$ of a $10^{9}-\mathrm{CFU} / \mathrm{ml}$ suspension of strain E278Ar in $0.25 \times$ modified Hoagland's solution (E278Ar), or $200 \mu \mathrm{l}$ of 2,6-dichloroisonicotinic acid (INA) at a rate of $50 \mu \mathrm{g} / \mathrm{ml}$ in distilled water. Plants were challenge-inoculated on the foliage with a $10^{8}-\mathrm{CFU} / \mathrm{ml}$ suspension of 704b 7 days following treatment with the biocontrol agent.

b Values represent the mean disease severity ratings for five experiments (two experiments in the case of plants treated with INA). True leaves (five replicates of five plants each per experiment) were rated for disease severity 6 to 8 days following challenge inoculation with 704b using a scale in which $1=$ symptomless; 2 = fewer than three lesions per leaf; $3=$ more than three lesions per leaf, less than $25 \%$ leaf area affected by disease; $4=$ lesions covering 25 to $50 \%$ of the leaf surface area; $5=$ lesions covering more than $50 \%$ of the leaf surface area; and $6=$ one or more leaves dead.

Populations of $704 \mathrm{~b}$ were determined by grinding the foliage of five plants per treatment in $0.25 \times$ modified Hoagland's and dilution plating on sucrosepeptone agar amended with streptomycin $(50 \mu \mathrm{g} / \mathrm{ml})$. Data shown are means of two experiments. The detection limit was $30 \mathrm{CFU}$ per $\mathrm{g}$ fresh weight of leaf tissue.

${ }^{\mathrm{d}}$ Least significant difference $(P=0.05)$ according to Fisher's method (7). 
roots of 3-day-old radish seedlings. To reduce the potential for colonization of leaves by E278Ar, the suspension was placed on the root at least $5 \mathrm{~cm}$ below the crown. The nutrient solution absorbed by the paper thus did not reach shoot tissue. Five to ten pouches (five seedlings per pouch) were used per treatment. In some experiments, roots were treated with INA $(50 \mu \mathrm{g}$ of active ingredient per $\mathrm{ml}$ of distilled water) at a rate of $200 \mu \mathrm{l}$ per root. To treat roots with $T$. hamatum strain $382,1 \mathrm{~g}$ of the granular inoculum preparation containing $2 \times 10^{8} \mathrm{CFU}$ of T382 per $\mathrm{g}$ was sprinkled onto the roots of the radish seedlings inside the pouch. This procedure placed approximately $10^{6} \mathrm{CFU} / \mathrm{ml}$ per $\mathrm{cm}$ of root. Controls were treated with $200 \mu \mathrm{l}$ of sterilized $0.25 \times$ modified Hoagland's solution per root. Pouches were arranged in a completely randomized design.

Challenge inoculation with $X$. campestris pv. armoraciae strain 704b. Radish seedlings were challenged with $X$. campestris pv. armoraciae strain $704 \mathrm{~b} 7$ days after treatment of roots with E278Ar. Inoculum of $704 \mathrm{~b}$ was grown for 20 to $48 \mathrm{~h}$ at $27^{\circ} \mathrm{C}$ on a rotary shaker in sucrose-peptone broth $(20 \mathrm{~g}$ of sucrose per liter and $5 \mathrm{~g}$ of Bacto peptone [Becton Dickinson] per liter amended with streptomycin [50 $\mu \mathrm{g} / \mathrm{ml}$; Sigma Chemical Co., St. Louis]). Cultures were then centrifuged at $3,840 \times g$ for $10 \mathrm{~min}$. A suspension of $2 \times$ $10^{8} \mathrm{CFU} / \mathrm{ml}$ prepared in sterile tap water with $0.02 \%$ Silwet L-77 (Lehle Seeds, Round Rock, TX) as a wetting agent was then sprayed to runoff onto radish seedlings. Controls were sprayed with $0.02 \%$ Silwet L-77 in autoclaved tap water. Preliminary experiments showed that Silwet used at this concentration did not induce ISR or symptoms of phytotoxicity. Plants were returned to the growth chamber for 4 to 5 days to allow development of symptoms.

Severity of bacterial spot on the first true leaves of seedlings was rated 4 to 5 days after challenge inoculation using a disease severity scale in which 1 = symptomless; 2 = fewer than three lesions per leaf; $3=$ more than three lesions per leaf, less than $25 \%$ leaf area affected by disease; $4=$ lesions covering 25 to $50 \%$ of the leaf surface area; $5=$ lesions covering more than $50 \%$ of the leaf surface area; and $6=$ one or more leaves dead. Disease severity data were

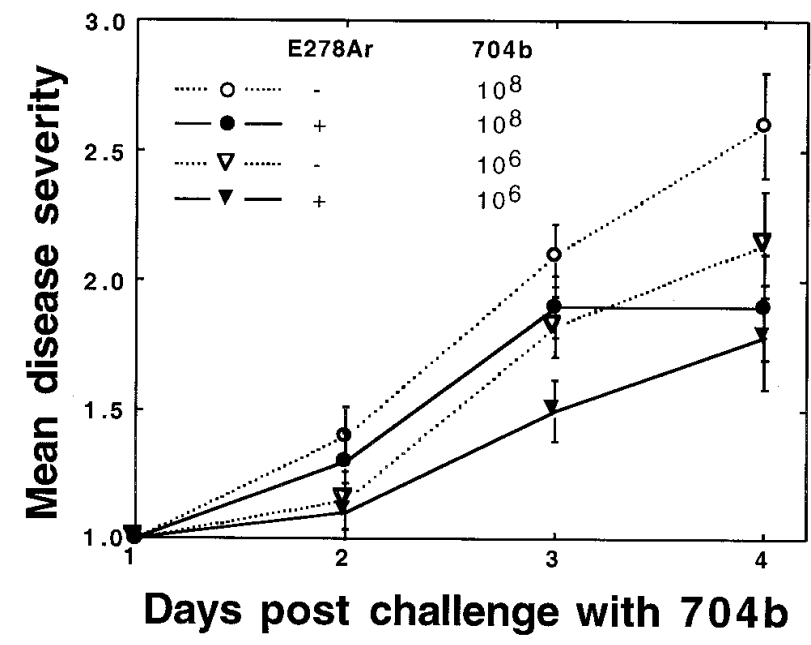

Fig. 2. Effect of challenge inoculum dose of Xanthomonas campestris pv. armoraciae strain $704 \mathrm{~b}$ on biological control of bacterial spot of radish induced by Pantoea agglomerans strain E278Ar applied to seedling roots. E278Ar was applied as a suspension of $10^{8} \mathrm{CFU} / \mathrm{ml}$ in $0.25 \times$ modified Hoagland's solution to roots of 3 -day-old seedlings ( $100 \mu \mathrm{l}$ per root, five replicates of five plants each). Control plants were treated with $0.25 \times$ modified Hoagland's solution ( $100 \mu \mathrm{l}$ per root). Plants were challenge-inoculated with $704 \mathrm{~b}$ 7 days after root treatment with E278Ar by spraying leaves to runoff with a suspension of either $10^{6}$ or $10^{8} \mathrm{CFU} / \mathrm{ml}$ in sterile tap water containing $0.02 \%$ Silwet L-77 as a wetting agent. Plants were incubated in a growth chamber under continuous light at $25^{\circ} \mathrm{C}$. True leaves were rated for disease symptoms 5 days following challenge inoculation with $704 \mathrm{~b}$ using a scale in which $1=$ symptomless; 2 = fewer than three lesions per leaf; $3=$ more than three lesions per leaf, less than $25 \%$ leaf area affected by disease; $4=$ lesions covering 25 to $50 \%$ of the leaf surface area; $5=$ lesions covering more than $50 \%$ of the leaf surface area; and $6=$ one or more leaves dead. analyzed by analysis of variance (ANOVA) and, when a significant $(P<0.05) F$ value was observed, separation of means was accomplished using Fisher's least significant difference (LSD) method (7).

Determination of biocontrol agent populations in planta. The population of the biocontrol agent E278Ar on roots was determined by grinding the roots of one seedling per pouch in $3 \mathrm{ml}$ of $0.1 \mathrm{M}$ phosphate buffer ( $\mathrm{pH} 7$ ) in a glass tissue homogenizer. This suspension was then plated on L-agar (L-broth with $1.7 \%$ Bacto agar) amended with $50 \mu \mathrm{g}$ of rifampicin per $\mathrm{ml}$ (three replicates per root), and the population was expressed as CFU per root. Populations on leaf surfaces were estimated by immersion of detached leaves (one plant per pouch) in $3 \mathrm{ml}$ of $0.1 \mathrm{M}$ phosphate buffer $(\mathrm{pH} 7)$ on a rotary shaker for $3 \mathrm{~h}$. The washate was then diluted and aliquots plated on Luria-Bertani agar with rifampicin. Populations on and in leaves were then determined by grinding individual leaves in phosphate buffer followed by dilution plating on L-agar with rifampicin. These two populations were expressed as CFU per $g$ fresh weight of leaf tissue.

Populations of T. hamatum strain 382 on the leaves and shoots were determined by grinding the foliage of one plant in $3 \mathrm{ml}$ of $0.01 \mathrm{M}$ phosphate buffer ( $\mathrm{pH}$ 7) followed by dilution plating on a Trichoderma selective medium (3).

The population of 704b was determined by grinding leaves of one plant per pouch as described above followed by dilution plating on sucrose-peptone agar with streptomycin $(50 \mu \mathrm{g} / \mathrm{ml}$; three replicates per plant). All population data were analyzed by ANOVA and, when a significant $(P<0.05) F$ value was observed, separation of means was accomplished using Fisher's LSD method (7).

Mini-Tn5Km mutagenesis of $P$. agglomerans strain E278Ar. Mini-Tn5Km was introduced into E278Ar using Escherichia coli strain SM10 $\lambda_{\text {pir }}$ (pUTmini-Tn5Km) (5) in an overnight mating on a solid surface. Transconjugants were selected on L-agar containing $50 \mu \mathrm{g}$ each of rifampicin and kanamycin per ml. The frequency of transposition was approximately $10^{-6}$ per recipient. Transconjugants were plated on both L-agar and M9 minimal medium (25). Individual colonies able to grow on both media were picked and stored at $-20^{\circ} \mathrm{C}$ in $25 \%$ glycerol. Putative mutants were screened using the growth pouch bioassay described above, and mutants showing a loss of biocontrol ability were tested twice more in the same bioassay.

\section{RESULTS}

$P$. agglomerans strain E278A and T. hamatum strain 382 suppress bacterial leaf spot. To determine whether root treatment with E278Ar reduced the severity of bacterial spot, roots of

TABLE 2. Suppression of bacterial spot of radish by root treatment with the fungal biocontrol agent Trichoderma hamatum strain 382 compared with Pantoea agglomerans strain E278Ar

\begin{tabular}{lcc}
\hline Root treatment & Pathogen inoculation $^{\mathrm{a}}$ & Mean disease severity $^{\mathrm{b}}$ \\
\hline Control & - & 1.0 \\
Control & + & 3.2 \\
E278Ar & + & 2.2 \\
T. hamatum strain 382 & + & 2.2 \\
LSD $_{0.05}{ }^{c}$ & & 0.6 \\
\hline
\end{tabular}

${ }^{a}$ Roots were treated 3 days after germination with $200 \mu$ of autoclaved $0.25 \times$ modified Hoagland's solution (control), $200 \mu \mathrm{l}$ of a $10^{9}-\mathrm{CFU} / \mathrm{ml}$ suspension of strain E278Ar in $0.25 \times$ modified Hoagland's solution, or approximately $1 \times 10^{6} \mathrm{CFU}$ of $T$. hamatum strain T382 per $\mathrm{g}$ per $\mathrm{cm}$ of root. Plants were challenge-inoculated with a $10^{8}$-CFU $/ \mathrm{ml}$ suspension of Xanthomonas campestris pv. armoraciae strain $704 \mathrm{~b} 7$ days following treatment with the biocontrol agent.

b Values represent the mean disease severity ratings for three experiments. True leaves (five replicates of five plants each per experiment) were rated for disease severity 6 to 8 days following challenge inoculation with 704b using a scale in which $1=$ symptomless; $2=$ fewer than three lesions per leaf; $3=$ more than three lesions per leaf, less than $25 \%$ leaf area affected by disease; $4=$ lesions covering 25 to $50 \%$ of the leaf surface area; $5=$ lesions covering more than $50 \%$ of the leaf surface area; and $6=$ one or more leaves dead.

${ }^{\mathrm{c}}$ Least significant difference $(P=0.05)$ according to Fisher's method (7). 
radish seedlings were treated with suspensions of the biocontrol agent and challenged with $X$. campestris pv. armoraciae strain $704 \mathrm{~b}$ 7 days later. Typical symptoms developed on the first true leaves of radish seedlings within 5 days after inoculation with the pathogen. Disease severity on treated seedlings was significantly $(P<$ 0.03 ) lower than that on control seedlings (Table 1). Similar results were obtained in five separate experiments. Untreated, uninoculated seedlings did not show any symptoms. Furthermore, seedlings treated with E278Ar but not inoculated with 704b also remained symptomless. Root treatment with E278Ar reduced the severity of bacterial spot when the foliage was sprayed with either a $10^{8}-\mathrm{CFU} / \mathrm{ml}$ suspension or a $10^{6}-\mathrm{CFU} / \mathrm{ml}$ suspension of $704 \mathrm{~b}$ (Fig. 2).

The population of $704 \mathrm{~b}$ was an order of magnitude lower on plants treated with E278Ar than that on control plants. It seemed to be reduced more by root treatment with INA than by treatment with E278Ar (Table 1). Neither the pathogen nor the biocontrol agent E278Ar were recovered from control plants not inoculated with either E278Ar or 704b. Finally, E278Ar and INA were equally effective in reducing disease severity (Table 1). Inoculation of the roots with T. hamatum strain 382 was as effective in reducing bacterial spot severity as was E278Ar in each of three experiments (Table 2).

Biocontrol agents applied to roots do not migrate to the foliage. Populations of E278Ar on roots and foliage of radish plants were followed to determine whether the biocontrol agent migrated from roots to shoots (Fig. 3). E278Ar grew on roots during the first $20 \mathrm{~h}$ after inoculation. Thereafter, its population per root remained the same. The final population ranged from $10^{6}$ to $10^{7} \mathrm{CFU}$ per root when E278Ar was inoculated at an initial concentration of $10^{8} \mathrm{CFU} / \mathrm{ml}$ and from $10^{4}$ to $10^{5} \mathrm{CFU}$ per root when inoculated at a concentration of $10^{4} \mathrm{CFU} / \mathrm{ml}$ (Fig. 3). Migration of E278Ar from the roots to the foliage was minimal. In one experiment, E278Ar was recovered from the foliage of 33\% of plants tested at the time of disease severity assessment. The mean population of E278Ar on and in the foliage of plants from which it was recovered was less than $100 \mathrm{CFU}$ per seedling. However, in a second and third experiment, E278Ar was not recovered from the foliage of any of 10 plants assayed per experiment, even though the severity of bacterial spot was significantly reduced in each. $T$. hamatum strain 382 was not detected in the foliage of radish plants treated on the roots with this biocontrol agent or on control seedlings in two separate experiments.

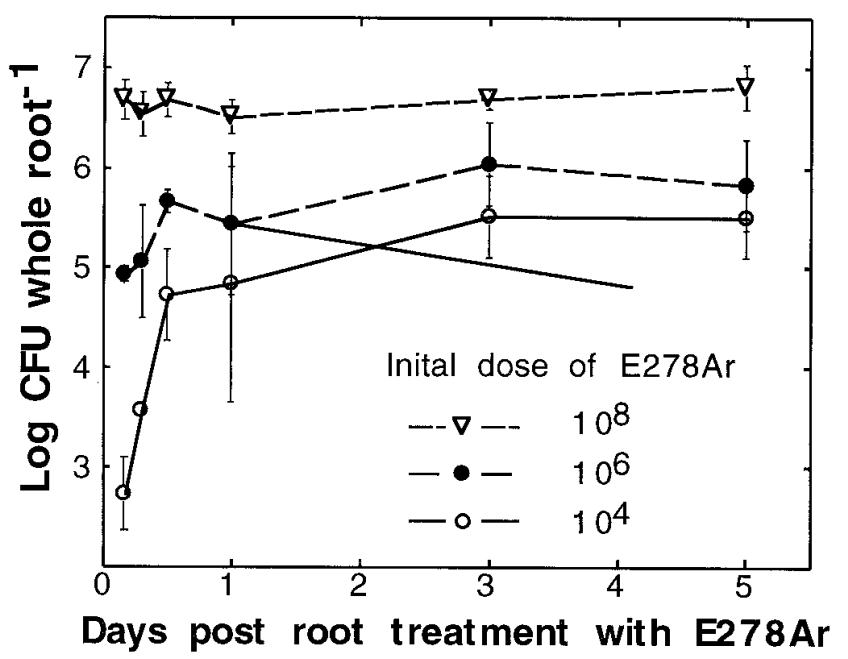

Fig. 3. Effect of initial inoculum dose of Pantoea agglomerans strain E278Ar on colonization of radish roots in growth pouches. Initial inoculum densities were $10^{4}, 10^{6}$, and $10^{8} \mathrm{CFU} / \mathrm{ml}$ in $0.25 \times$ modified Hoagland's solution. E278Ar was applied to roots by dripping $100 \mu \mathrm{l}$ of a suspension onto 3-day-old roots. Entire root systems (five plants per treatment) were harvested and ground in a glass tissue homogenizer and then diluted and plated onto L-agar with rifampicin $(50 \mu \mathrm{g} / \mathrm{ml})$. Colonies were counted after incubation for $24 \mathrm{~h}$ at $30^{\circ} \mathrm{C}$.
Mutants of E278Ar unable to reduce the severity of bacterial leaf spot. Only 3 of 672 mini-Tn5Km insertion mutants tested were identified in preliminary screenings as having lost the ability to control bacterial spot. Bacterial spot was as severe on plants treated with mutants $3 \mathrm{C} 8,3 \mathrm{E} 12$, and $4 \mathrm{C} 12$ as on controls treated with modified Hoagland's solution in each of two experiments (Table 3). Each of these mutants colonized radish roots as well as the wildtype strain when inoculated at a concentration of $10^{8} \mathrm{CFU}$ per root (Fig. 4).

\section{DISCUSSION}

We previously reported that E278Ar induces systemic resistance to anthracnose of cucumber in compost-amended potting mixes fortified with this biocontrol agent $(45,46)$. The anthracnose bioassay, like most other bioassays used for screening of biocontrol agents, requires almost 1 month to complete. Such long-term bioassays are difficult to use in large screening trials. On the other hand, the radish growth pouch assay developed in this study offers the advantage of a short assay period (14 to 18 days) and requires only a small amount of growth chamber space to test many different strains or isolates. The data presented here established that this rapid growth pouch radish seedling bioassay can be used effectively to screen large numbers of microorganisms for ISR activity while maintaining spatial separation between the biocontrol agent and the pathogen. The bacterial biocontrol agent E278Ar colonized the radish roots (Fig. 3), but essentially did not migrate into the foliage of plants after inoculation onto roots. A fungal biocontrol agent, $T$. hamatum strain 382 , likewise did not migrate to the foliage of radish plants. This indicates that spatial separation between the pathogen and the biocontrol agent on the host was maintained and that truly systemic effects were observed, since there was little opportunity for direct interactions between the agents and the pathogen. Even though plants were grown closely together, cross-contamination of biocontrol agents among pouches was not a problem. E278Ar was not recovered from control pouches, even though they were located in a rack next to those treated with E278Ar. Our results with E278Ar and T. hamatum strain 382 suggest that this new growth pouch bioassay was well suited for studies of inducers of systemic resistance to pathogens such as X. campestris pv. armoraciae that develop symptoms fully within a few days after inoculation. Furthermore, this bioassay should prove useful for screening chemicals for induction of resistance, as demonstrated by our

TABLE 3. Loss of suppression of bacterial spot of radish in plants treated on the roots with mini-Tn5Km mutants of Pantoea agglomerans strain E278Ar

\begin{tabular}{lcc}
\hline Root treatment & Pathogen inoculation & Mean disease severity $^{\mathrm{b}}$ \\
\hline Control & - & 1.0 \\
Control & + & 3.3 \\
E278Ar (wild type) & + & 2.4 \\
Mutant 3C8 & + & 3.2 \\
Mutant 3E12 & + & 3.2 \\
Mutant 4C12 & + & 2.9 \\
LSD $_{0.05}{ }^{c}$ & & 0.5
\end{tabular}

a Roots were treated 3 days after germination with $200 \mu$ of autoclaved $0.25 \times$ modified Hoagland's solution (control) or $200 \mu \mathrm{l}$ of a $10^{9}-\mathrm{CFU} / \mathrm{ml}$ suspension of strain E278Ar in $0.25 \times$ modified Hoagland's solution. Plants were challenge-inoculated with a $10^{8}-\mathrm{CFU} / \mathrm{ml}$ suspension of Xanthomonas campestris pv. armoraciae strain $704 \mathrm{~b} 7$ days following treatment with the biocontrol agent.

b Values represent the mean disease severity ratings for two experiments. True leaves (five replicates of five plants each per experiment) were rated for disease severity 6 to 8 days following challenge inoculation with 704b using a scale in which $1=$ symptomless; 2 = fewer than three lesions per leaf; $3=$ more than three lesions per leaf, less than $25 \%$ leaf area affected by disease; $4=$ lesions covering 25 to $50 \%$ of the leaf surface area; $5=1 \mathrm{e}$ sions covering more than $50 \%$ of the leaf surface area; and $6=$ one or more leaves dead.

c Least significant difference $(P=0.05)$ according to Fisher's method (7). 
results with INA. The nature of the systemic resistance induced by E278Ar and T. hamatum strain 382 remains to be characterized, but we speculate that it is probably ISR. Preliminary northern blots indicated that PR proteins known to be induced by the SAR pathway were not expressed (D. Y. Han, unpublished data). As more is known about the ISR pathway, we expect that it will soon be possible to test for the induction of specific ISR proteins.

A disadvantage of the pouch bioassay is that it cannot be used for long-term growth trials. In the current assay, with five seedlings per pouch, the seedlings became etiolated and collapsed after 21 days. The density of seedlings would have to be reduced considerably to avoid this problem. In addition, after 21 days, the seedlings required more water than could be provided by the paper wick system. Therefore, this bioassay is best used for short-term applications. It is not suited to following the effects of a biocontrol agent over a period of many weeks.

We demonstrated that E278Ar was as effective as INA in inducing systemic resistance in radish to bacterial spot (Table 1). This may seem to contradict Hoffland et al. (11), who reported that INA applied to radish roots did not induce systemic resistance against Fusarium wilt, although SA did. However, they based this conclusion on observations of disease incidence, not of disease severity (11). They found that Pseudomonas fluorescens strain WCS417 and SA reduced the incidence of Fusarium wilt of radish, but not its severity. We found that, whereas disease incidence was not affected by any of our treatments, disease severity was reduced by root treatment with INA, E278Ar, and T. hamatum strain 382 (Tables 1 and 2).

Specific mutations have been made in biocontrol agents in the past to test whether certain gene products such as SA (30) or lipopolysaccharides (19) are necessary for induction of systemic resistance. As we noted in preliminary screening trials (46), the ability to induce systemic resistance seems to be a rare phenomenon among bacterial biocontrol agents. The growth pouch bioassay described here offers the possibility of conducting general, systematic searches for genes required for induction of systemic resistance by biocontrol agents.

In this regard, we have used this bioassay successfully to identify three mini-Tn5Km mutants of E278Ar that had lost their ability to induce systemic resistance in radish. The growth of these mutants on artificial media was not altered and their ability to colonize and survive on roots did not differ from the wild type (Fig. 4), suggesting that the mutations may have been specific to produc-

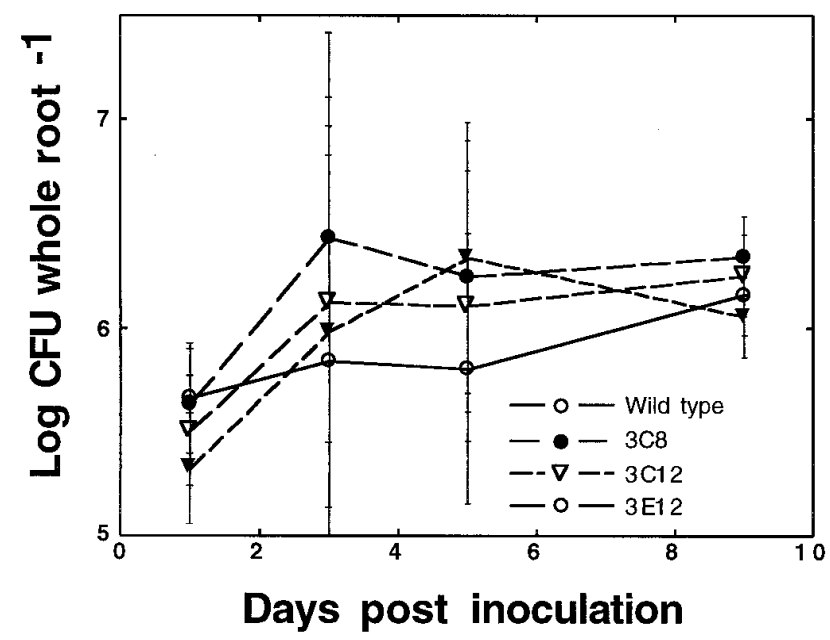

Fig. 4. Colonization of radish roots by wild-type Pantoea agglomerans strain E278Ar and three selected mini-Tn5 insertion mutants. All bacteria were inoculated onto radish roots at a rate of $10^{8} \mathrm{CFU}$ per root $\left(100 \mu \mathrm{l}\right.$ of a $10^{9}-$ $\mathrm{CFU} / \mathrm{ml}$ suspension in $0.25 \times$ modified Hoagland's solution) and entire root systems (five roots per treatment) were ground in a tissue homogenizer, diluted in $0.25 \times$ modified Hoagland's, and plated on L-agar plus rifampicin $(50 \mu \mathrm{g} / \mathrm{ml})$. Colonies were counted after incubation for $24 \mathrm{~h}$ at $30^{\circ} \mathrm{C}$. tion of an ISR elicitor molecule. In preliminary experiments (D. Y. Han and D. L. Coplin, unpublished data), we also used this assay to show that cell-free extracts from E278Ar contain a protease-sensitive elicitor of systemic resistance, and we expect that this assay will be useful in purifying the putative elicitor and in determining and the nature of the systemic resistance induced by E278Ar.

\section{ACKNOWLEDGMENTS}

This work was supported by grants from USDA-IR-4, Cook College, Rutgers University, P.O. Box 231, New Brunswick, NJ; from USDASARE grant number LWF62-016-03607; and from Gustafson Inc., P.O. Box 660065, Dallas, TX. Salaries and research support provided by state and federal funds appropriated to the Ohio Agricultural Research and Development Center, The Ohio State University. D. Y. Han was the recipient of a Director's Fellowship from the Ohio Agricultural Research and Development Center. We thank D. R. Majerczak and C. A. Musselman for providing excellent technical assistance and T. L. Graham for critical reading of the manuscript.

\section{LITERATURE CITED}

1. Alexander, D., Stinson, J., Pear, J., Glascock, C., Ward, E., Goodman, R. M., and Ryals, J. 1992. A new multigene family inducible by tobacco mosaic virus or salicylic acid in tobacco. Mol. Plant-Microbe Interact. 5:513-515.

2. Chang, P. F. L., Xu, Y., Narasimhan, M. L., Cheah, K. T., D'Urzo, M. P., Damsz, B., Kononowicz, A. K., Abad, L., Hasegawa, P. M., and Bressan, R. A. 1997. Induction of pathogen resistance and pathogenesis-related genes in tobacco by a heat-stable Trichoderma mycelial extract and plant signal messengers. Physiol. Plant. 100:341-352.

3. Chung, Y. R., and Hoitink, H. A. J. 1990. Interactions between thermophilic fungi and Trichoderma hamatum in suppression of Rhizoctonia damping-off in a bark compost-amended container medium. Phytopathology 80:73-77.

4. Delaney, T. P. 1997. Genetic dissection of acquired resistance to disease. Plant Physiol. 113:5-12.

5. De Lorenzo, V., Herrero, M., Jakubzik, U., and Timmis, K. N. 1990. Mini-Tn5 transposon derivatives for insertion mutagenesis, promoter probing and chromosomal insertion of cloned DNA in Gram-negative eubacteria. J. Bacteriol. 172:6568-6572.

6. De Meyer, G., Bigirimana, J., Elad, Y., and Hofte, M. 1998. Induced systemic resistance in Trichoderma harzianum T39 biocontrol of Botrytis cinerea. Eur. J. Plant Pathol. 104:279-286.

7. Fisher, R. A. 1949. The Design of Experiments. Oliver and Boyd, Edinburgh, United Kingdom.

8. Görlach, J., Volrath, S., Knauf-Beiter, G., Hengy, G., Beckhove, U., Kogel, K.-H., Oostendorp, M., Staub, T., Ward, E., Kessmann, H., and Ryals, J. 1996. Benzothiadiazole, a novel class of inducers of systemic acquired resistance, activates gene expression and disease resistance in wheat. Plant Cell 8:629-643.

9. Hoagland, D. R., and Arnon, D. R. 1938. The water culture method for growing plants without soil. Calif. Agric. Exp. Stn. Bull. 347:36-39.

10. Hoffland, E., Hakulinen, J., and van Pelt, J. A. 1996. Comparison of systemic resistance induced by avirulent and nonpathogenic Pseudomonas species. Phytopathology 86:757-762.

11. Hoffland, E., Pieterse, C. M. J., Bik, L., and van Pelt, J. A. 1995. Induced systemic resistance in radish is not associated with accumulation of pathogenesis-related proteins. Physiol. Mol. Plant Pathol. 46:309-320.

12. Keller, H., Bonnet, P., Galiana, E., Pruvot, L., Friedrich, L., Ryals, J., and Ricci, P. 1996. Salicylic acid mediates elicitin-induced systemic acquired resistance, but not necrosis in tobacco. Mol. Plant-Microbe Interact. 9:696-703.

13. Kessmann, H., Staub, T., Hoffman, C., Maetzke, T., Herzog, J., Ward, E., Uknes, S., and Ryals, J. 1994. Induction of systemic acquired resistance in plants by chemicals. Annu. Rev. Phytopathol. 32:439-459.

14. Kloepper, J. W., Tuzun, S., and Kuć, J. A. 1992. Proposed definitions related to induced disease resistance. Biocontrol Sci. Technol. 2:349-351.

15. Kunz, W., Schurter, R., and Maetzke, T. 1997. The chemistry of benzothiadiazole plant activators. Pestic. Sci. 50:275-282.

16. Kwok, O. C. H., Fahy, P. C., Hoitink, H. A. J., and Kuter, G. A. 1987. Interactions between bacteria and Trichoderma hamatum in suppression of Rhizoctonia damping-off in bark compost media. Phytopathology 77: 1206-1212.

17. Leeman, M., den Ouden, F. M., van Pelt, J. A., Dirkx, F. P. M., Steijl, H., Bakker, P. A. H. M., and Schippers, B. 1996. Iron availability affects induction of systemic resistance to Fusarium wilt of radish by Pseudo- 
monas fluorescens. Phytopathology 86:149-155.

18. Leeman, M., van Pelt, J. A., den Ouden, F. M., Heinsbroek, M., Bakker, P. A. H. M., and Schippers, B. 1995. Induction of systemic resistance by Pseudomonas fluorescens in radish cultivars differing in susceptibility to Fusarium wilt, using a novel bioassay. Eur. J. Plant Pathol. 101:655-664.

19. Leeman, M., Van Pelt, J. A., Den Ouden, F. M., Heinsbroek, M., Bakker, P. A. H. M., and Schippers, B. 1995. Induction of systemic resistance against Fusarium wilt of radish by lipopolysaccharides of Pseudomonas fluorescens. Phytopathology 85:1021-1027.

20. Liu, L., Kloepper, J. W., and Tuzun, S. 1995. Induction of systemic resistance in cucumber against Fusarium wilt by plant growth-promoting rhizobacteria. Phytopathology 85:695-698.

21. Liu, L., Kloepper, J. W., and Tuzun, S. 1995. Induction of systemic resistance in cucumber against bacterial angular leaf spot by plant growthpromoting rhizobacteria. Phytopathology 85:843-847.

22. Maurhofer, M., Reimmann, C., Schmidli-Sacherer, P., Heeb, S., Haas, D., and Défago, G. 1998. Salicylic acid biosynthetic genes expressed in Pseudomonas fluorescens strain P3 improve the induction of systemic resistance in tobacco against tobacco necrosis virus. Phytopathology 88 : 678-684.

23. Meera, M. S., Shivanna, M. B., Kageyama, K., and Hyakumachi, M. 1994. Plant growth promoting fungi from zoysiagrass rhizosphere as potential inducers of systemic resistance in cucumbers. Phytopathology 84:1399-1406.

24. Métraux, J. P., Signer, H., Ryals, J., Ward, E., Wyss-Benz, M., Gaudin, J., Rachsdorf, K., Schmid, E., Blum, W., and Inverardi, B. 1990. Increase in salicylic acid at the onset of systemic acquired resistance in cucumber. Science 250:1004-1006.

25. Miller, J. H. 1992. A Short Course in Bacterial Genetics. Cold Spring Harbor Laboratory Press, Cold Spring Harbor, NY.

26. Mitter, N., Kazan, K., Way, H. M., Broekaert, W. F., and Manners, J. M. 1998. Systemic induction of an Arabidopsis plant defensin gene promoter by tobacco mosaic virus and jasmonic acid in transgenic tobacco. Plant Sci. 136:169-180.

27. Palva, T. K., Hurtig, M., Saindrenan, P., and Palva, E. T. 1994. Salicylic acid induced resistance to Erwinia carotovora subsp. carotovora in tobacco. Mol. Plant-Microbe Interact. 7:356-363.

28. Pieterse, C. M. J., van Wees, S. C. M., Hoffland, E., van Pelt, J. A., and van Loon, L. C. 1996. Systemic resistance in Arabidopsis induced by biocontrol bacteria is independent of salicylic acid accumulation and pathogenesis-related gene expression. Plant Cell 8:1225-1237.

29. Pieterse, C. M. J., van Wees, S. C. M., van Pelt, J. A., Knoester, M., Laan, R., Gerrits, H., Weisbeek, P. J., and van Loon, L. C. 1998. A novel signaling pathway controlling induced systemic resistance in Arabidopsis. Plant Cell 10:1571-1580.

30. Press, C. M., Wilson, M., Tuzun, S., and Kloepper, J. W. 1997. Salicylic acid produced by Serratia marcescens $90-166$ is not the primary determinant of induced systemic resistance in cucumber or tobacco. Mol. Plant-Microbe Interact. 10:761-768.
31. Raupach, G. S., Liu, L., Murphy, J. F., Tuzun, S., and Kloepper, J. W. 1996. Induced systemic resistance in cucumber and tomato against cucumber mosaic cucumovirus using plant growth-promoting rhizobacteria (PGPR). Plant Dis. 80:891-894.

32. Ross, A. F. 1961. Systemic acquired resistance induced by localized virus infections in plants. Virology 14:340-358.

33. Ryals, J., Neuenschwander, U. H., Willits, M. G., Molina, A., Steiner, H.-Y., and Hunt, M. D. 1996. Systemic acquired resistance. Plant Cell 8: 1809-1819.

34. Ryals, J., Uknes, S., and Ward, E. 1994. Systemic acquired resistance. Plant Physiol. 104:1109-1112.

35. Sahin, F., and Miller, S. A. 1997. A new pathotype of Xanthomonas campestris pv. armoraciae that causes bacterial leaf spot of radish. Plant Dis. $81: 1334$.

36. Sticher, L., Mauch-Mani, B., and Métraux, J. P. 1997. Systemic acquired resistance. Annu. Rev. Phytopathol. 35:235-270.

37. Tuzun, S., and Kuć, J. 1987. Persistence of systemic resistance to blue mold in tobacco plants derived via tissue culture. Phytopathology 77: 1032-1035.

38. Tuzun, S., Rao, M. N., Vogeli, U., Schardl, C. L., and Kuć, J. 1989. Induced systemic resistance to blue mold: Early infection and accumulation of $\beta$-1,3-glucanases, chitinases and other pathogenesis-related proteins (b-proteins) in immunized tobacco. Phytopathology 79:979-983.

39. van Wees, S. C. M. 1999. Rhizobacteria-mediated induced systemic resistance in Arabidopsis: Signal transduction and expression. Ph.D. dissertation. Utrecht University, Utrecht, the Netherlands.

40. Van Wees, S. C. M., Pieterse, C. M. J., Trijssenaar, A., Van 't Westende, Y. A. M., Hartog, F., and Van Loon, L. C. 1997. Differential induction of systemic resistance in Arabidopsis by biocontrol bacteria. Mol. PlantMicrobe Interact. 10:716-724.

41. Vernooij, B., Friedrich, L., Goy, P. A., Staub, T., Kessmann, H., and Ryals, J. 1995. 2,6-Dichloroisonicotinic acid-induced resistance to pathogens without the accumulation of salicylic acid. Mol. Plant Microbe Interact. 8:228-234.

42. Ward, E. R., Uknes, S. J., Williams, S. C., Dincher, S. S., Wiederhold, D. L., Alexander, D. C., Ahl-Goy, P., Métraux, J. P., and Ryals, J. A. 1991. Coordinate gene activity in response to agents that induce systemic acquired resistance. Plant Cell 3:1085-1094.

43. Wei, G., Kloepper, J. W., and Tuzun, S. 1991. Induction of systemic resistance of cucumber to Colletotrichum orbiculare by select strains of plant growth-promoting rhizobacteria. Phytopathology 81:1508-1512.

44. Wei, G., Kloepper, J. W., and Tuzun, S. 1996. Induced systemic resistance to cucumber diseases and increased plant growth by plant growth-promoting rhizobacteria under field conditions. Phytopathology 86:221-224.

45. Zhang, W., Dick, W. A., and Hoitink, H. A. J. 1996. Compost-induced systemic acquired resistance in cucumber to Pythium root rot and anthracnose. Phytopathology 86:1066-1070.

46. Zhang, W., Han, D. Y., Dick, W. A., Davis, K. R., and Hoitink, H. A. J. 1998. Compost and compost water extract-induced systemic acquired resistance in cucumber and arabidopsis. Phytopathology 88:450-455. 